\title{
The Enhancement Adversity Quotient Through Outbound Play Activities
}

\author{
Myrnawati Crie Handini, Linda Nur Hasanah \\ Post Graduate of Early Childhood Education, Jakarta State University \\ Corresponding e-mail: mynawati@unj.ac.id
}

\begin{abstract}
The objective of the research was to explain the process a learning outcomes of learning thought outbound activities to increase adversity quotient kindergarten the subject of research are 16 children. The method used in this research is an action research which refers to the model of a Classroom Action Research Kemmis and Mc. Taggart consist of four phase: planning, actions. Observation and reflection. This research consist of two cycles, each cycle consisting of 12 times in actions. The data analysis technique used in this research are a quantitative analysis. Analysis of data reduction, data display and data verification. Analysis of quantitative data descriptive statistics that compare the results obtained from pre-cycle, the first cycle and the second cycle. The result of research that increase adversity quotient of children through outbound activities, it can be evidenced scoring average pre-cycle is 24,31 , the first cycle is 32,94 and the second cycles $44,20$.
\end{abstract}

Keywords: adversity quotient, outbound

\section{INTRODUCTION}

Maturation of human growth and development depends on the experience they have gone through in the past. The experience is a manifestation of behavior that has been done consciously so that it can be the key for him to open up and form a more tangible learning moment in his life. The learning moments are not only to be done formally, but can also occur informally in an unconscious form; through direct contact and blending with the environment that are within their neighborhood. This approach is a more progressive standpoint, where the values of self, as well as the attitude, struggle and hard work that are not written textually in any curriculum can be simply internalized. Where such elements are important factors in learning that indirectly support and accelerate the achievement of success in one's life.

Attitudes and values born from learning approaches based on the sensitivity of the surrounding environment can be started from developing the intelligence of adversity quotient. Adversity quotient intelligence is an intelligence one's possess to overcome difficulties in order to survive, in this case not easily giving up when faced with difficulties or obstacles in life. Someone will live from stage to stage, the higher the stage, the obstacles encountered will be even greater, so a person should have the intelligence to survive, therefore Adversity quotient must be instilled early. Adversity quotient is not something that is obtained instantly or inborn but rather something that can be trained, formed or created.

With the rapid development of information technology today, many children are more obsessed with the presence of the virtual world. Characteristic of technology that offers a variety of processes and access to many information instantly, resulting in children less interested in interacting, going through a process, and impatient in the face of obstacles and difficulties in life. Children who frequently use gadgets, will be more easily satisfied in obtaining knowledge, in the sense that many are obtained through the gadget. Gadgets make children become instant thinker and lazy in doing something as well as the override undermining the process. This causes the tenacity and fighting spirit of children has declined.

According to the observations of researchers in learning activities and daily activities in Kindergarten, children aged 5-6 years in group B is yet to have adversity quotient. Looks children still 
ask awaited by parents when leaving school up to class. Crying when they are asked to line up before entering the classroom, complain easily, order teacher to help when they got into trouble opening their lunchbox, and crying when they lose something.

Effective methods as an effort to overcome the lacking of adversity quotient at Kindergarten, is by playing. Outbound is a game that provides challenges and obstacles that are packed in a fun package and is open in nature. Outbound offers variety of games that corresponding to the level of strength and courage of the involved children in order to become an alternative to help adversity quotient problem of a child.

\subsection{Adversity Quotient}

Ari (2011: 387) mentions adversity quotient as an intelligence that one possess to overcome difficulties in order to survive. Adversity Quotient is the level of a person's ability to survive and pass through all the difficulties in their daily lives to achieve success that everyone wants.

Thus expresses by Haryanto (2010: 319) adversity quotient gives an idea of how much a person can survive adversity and ability to cope with it, simply said Adversity Quotient discusses why someone easily give up and a few others have the extraordinary power to face challenges. As long as a person is alive he will surely find obstacles in their daily life and the higher the degree or level of a person's, problems or difficulties will be even greater as well. As is stated by Liisa (2010: 113) Tenacity, persistence, and toughness, perhaps even hardheadedness, in the face of adversity. It is a personal (or national) quality, one that may be necessary to survive. Difficulties and obstacles in everyday life cannot be avoided, it comes and goes. Adversity quotient that encourage someone to keep going in his life.

Agreeing with Stoltz (2000: 8), adversity quotient tells you how much a person endure hardship and able to cope it. Adversity Quotient predicts who will exceed expectations for their performance and their potential and who will fails, adversity quotient also predicts who will give up and who will survive.

Make effort and always pray to the creator is the principal that must be possessed by someone. As Nelson in Ahmad (2013: 55) said, adversity quotient describes a physical, mental, and spiritual endurance to cope with rapid changes. The difficulty is partly a test of faith, with wisdom one would always try and work hard to get through the difficulties.
Individual effort in achieving success is described by Stolts as people climbing up the mountain. Stolts mountain climbing categorize people into three types; (1) those who quit (quitters), (2) those who camp (campers), and (3) those who are true climbers (climbers). They are a climber that their level of determination can be seen by the beauty presented by the mountain to them. Sroltz also divides the determinants of the adversity quotient into four main components (dimensions). These four dimensions describe what moves and what is impeding the realization of the potential of each individual. These dimensions are control, origin and ownership, reach and endurance.

Based on the description above, it can be concluded that the adversity quotient (adversity quotient) is one's ability to understand and use all sources of power to overcome difficulties and obstacles in life in a constructively and consistently which includes aspects: 1) control 2) the Origin and ownership 3) Reach, 4) Endurance.

\subsection{Outbound}

Badiatul (2008: 5) also expressed the opinion that outbound is as fun activities and challenging. The form of the activity is the simulation of life through creative, recreational, and educational games either individually or in groups for the purpose of selfdevelopment personal development or team development.

Ashok (2007:361) The outbound set-up gives challenges and obstacles like real life situations which participants have to learn to overcome. Outbound has a goal to train the cooperation between partners. Increasing the motivation and growing unyielding mentality to reach an outcome.

Djamalludin Ancok (2009: 11) states that team development in outbound activity has purpose to stimulate emotion, starting from an easy and fun task with not much challenge, gradually increasing to self-development activities that demand more courage. In line with one's spirit or enthusiasm in participating the outbound activities, the team work between team members will be increasing as well.

Esnoe (2010: 14) also said that outbound is a medium of education in the open natural from of a shortage then transform it into an advantages. In the outbound activities, a person's chance to express thought, think and respect for others will be well trained. It has prompted various organizations to use outbound as their training media. Outbound activity when used as one of additional activities in teaching methods can encourage the spirit a child to learn.

Outbound not only provides games and specific purpose, but also provides a wide range of enormous benefits to the participants. In general, the benefits 
of outbound described by As'adi (2009: 26) is that this open nature activity is beneficial to increase the courage to act and thought, outbound establish a creative mindset, and improving emotional intelligence and spiritual interaction.

From the description above can be synthesized outbound is an action done in the open nature (outdoor) and is presented in the form of games, simulations, discussions and adventure.

\section{METHOD}

The method used is action research. Geoffrey (200:6) propose Action Research is any systematic inquiry conducted by teacher research's, principals, school counselor, or other stakeholders in the teaching /learning environment to gather information about the ways that their particular school operate, how they teach, and how well their students learn. This action research uses Kemmis \& Mc Taggart model design which includes four stages: planning, action, observation, reflection. Triyanto (2011:29) Model Kemmis \& Taggart is a development of the basic concepts introduced Kurt Lewin, it's just acting and observing components used as a single entity since they are an integral action, occurred in the same time. Model Kemmis \& Taggart is a basic concept introduced development of. Kurth Lewin, it's just acting and observing components used as a single entity since they are an integral action, occurred in the same time. Data collection uses qualitative and quantitative techniques. The techniques used are the triangulation of data, done by checking the truth, hypotheses and construct. Validity is done based on a synthesis of the theories about the concept of the variables that is to be measured through a logic and process of analysis. This study is successful when at least $71 \%$ of the numbers of children which are 12 of the 16 children reach the minimum Development Achievement Level (DAL) scores that is previously specified along with collaborator. In this study, minimum DAL score is $75 \%$ of the maximum DAL.

This research is conducted Sragen with 16 children consists of 10 boys and 6 girls as respondents and two collaborators. And is implemented from January to March, 2016.

Data obtained in this research are quantitative and qualitative data. The quantitative data are in the form of pre-intervention scores and cycle scores while the qualitative data are from the child's development when going through the learning activities. Lesson plan is in the form of play activity programs and data on the observation phase of implementation. Sources of data in this study were children in group B Kindergarten. Group B is the primary data source. Another data sources to see increased adversity quotient of children aged 5-6 years is by conducting interview toward teachers and principals as collaborators involved in the study.

Data collection techniques used in this study are a non-test. Data collection procedures using observation instruments that contain indicators of success of the action. In collecting the data, the researcher is assisted by the class teacher as collaborator to measure the development of adversity quotient of children before and after being treated. Instruments designed by researchers are based on adversity quotient theories. Observations have been selected as the primary technique in this study because the study will look at the behavior or attitude of men which is adversity quotient of the children. Through observations researcher notices change of the children's adversity quotient before and after they are treated with the action. The data collection techniques also include documentation. Documentation is used as evidence that the child has gone through the many processes during the study period.

Researchers conduct an analysis of the overall findings in the process in order to improve the adversity quotient of kindergarten children through outbound activities. The analysis is performed with quantitative and qualitative approaches. Qualitative data analysis presents the findings of the field deep and meaningfully. Data analysis is performed since before entering the field, during the field and after the completion of the field. Analysis before entering the field, is conducted by collecting data from a teacher or observations made by comparing the results obtained pra-intervention, cycle 1 and 2 . The result from cycle 1 and 2, for 12 sessions per cycle with a range of weights: not observable worth one (1), Start being observable worth two (2), well observed worth three (3) in order to obtain an overview of progress of the effectiveness of outbound play activities that are expected to emerge in children in group B Kindergarten, Sambirejo, Sragen. The data are calculated through analysis of quantitative data such as the average number or scores. While in qualitative data analysis, data are showed in form of descriptive words.

\section{FINDING AND DISCUSSION}

Pre-cycle shows that adversity quotient development of children in the category yet to be seen, with an average score of 24,31 points. 


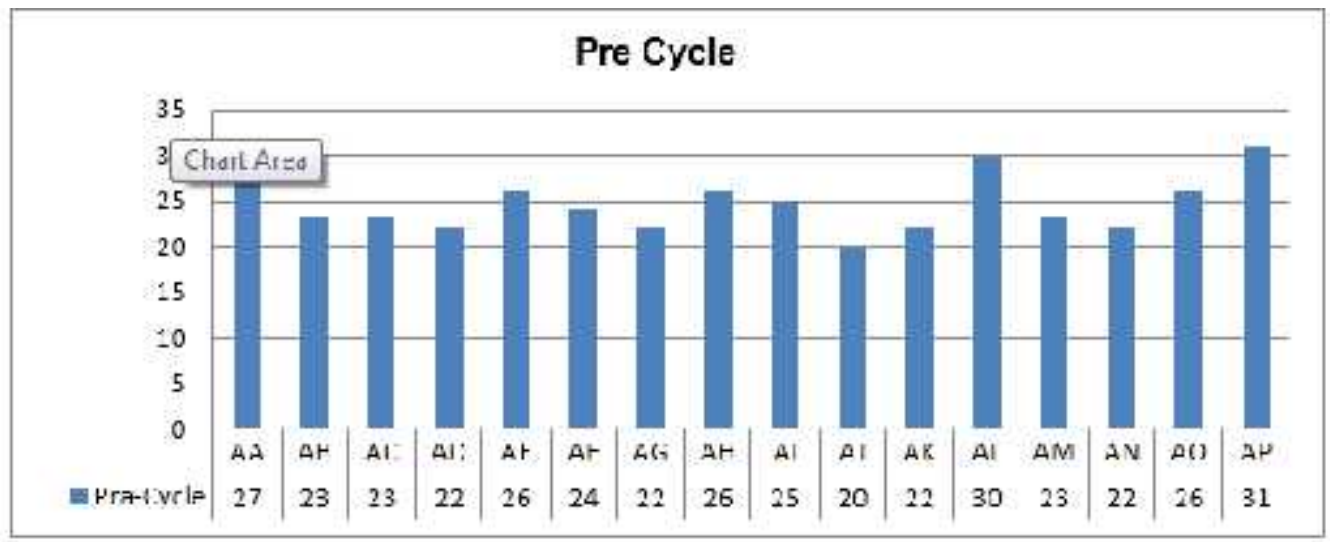

Figure 1. Pre-Cycle Adversity Quotient Graphic to Group B Children of Kindergarten

The graph above shows that the average DAL children development adversity quotient kindergartener B on pre-cycle is the category has not been observed, namely DEL Children with an average grade 24.31 Of the 16 children showed AJ DAL Kids get low of 20 and AP DAL Kids getting high of 31 .

\subsection{Cycle 1}

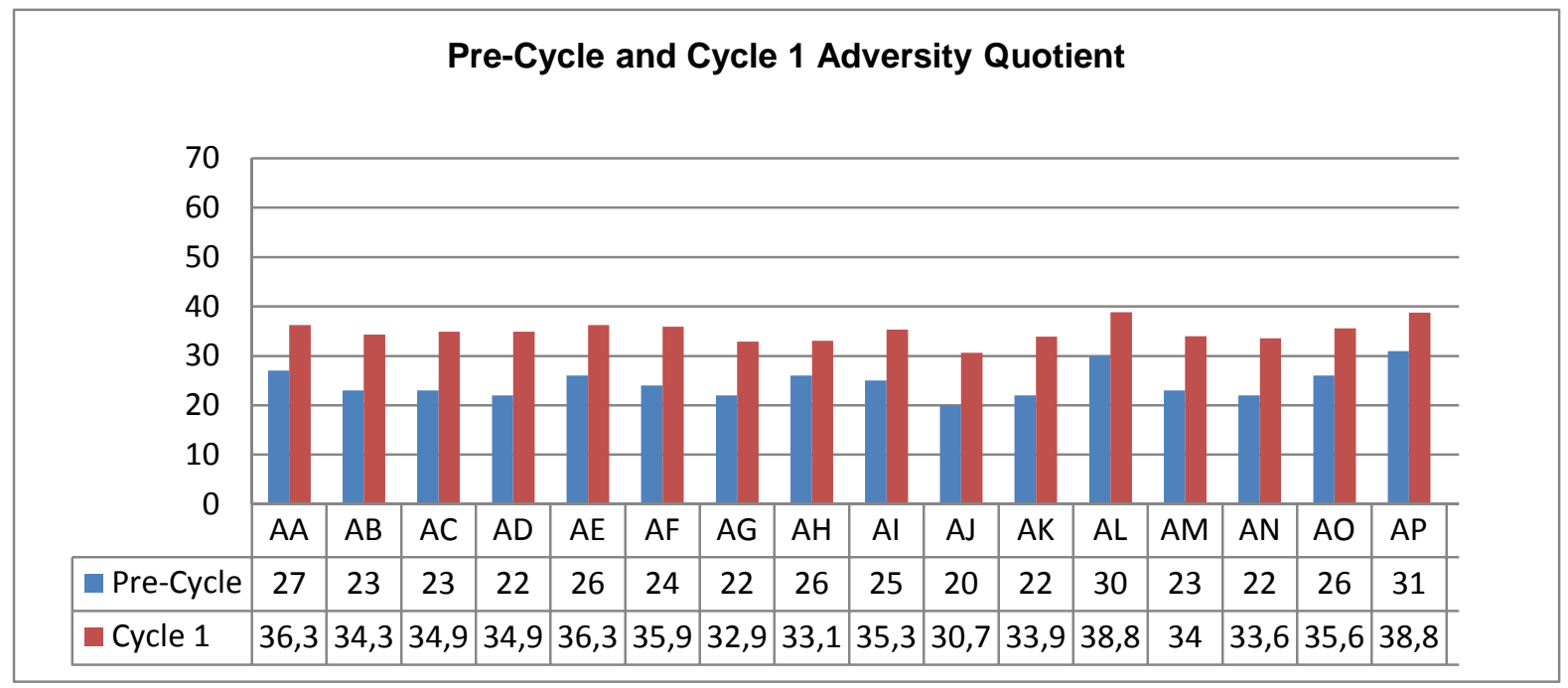

Figure 2. Cycle 1 Adversity Quotient Graphic to Group B Children of Kindergarten

The data on the graph above shows an increase in adversity quotient of children before playing outbound activities until it gets to the first cycle that has gained time playing outbound activities. The graph shows adversity quotient development of Group B kindergarten totaling 16 people reached 34.95 points in first cycle compared to pre-cycle with 24,31 points. It shows an average increase of adversity quotient by 10.34 points

If seen from the success criteria, with 40.5 points as minimal score, the results of the first cycle shows that of the pre-intervention to the first cycle, DAL of children has increased but has not reached the target. So this research will be continued in the second cycle because $71 \%$ or 12 of the children has not reached the minimum DAL that is previously specified with collaborator. Implementation of the second cycle is done with some improvements based on the results of the cycle 1 . 


\subsection{Cycle 2}

Observations on the second cycle is conducted to determine the children's score that is obtained after outbound activities play done. The observational data on the second cycle is as follows:

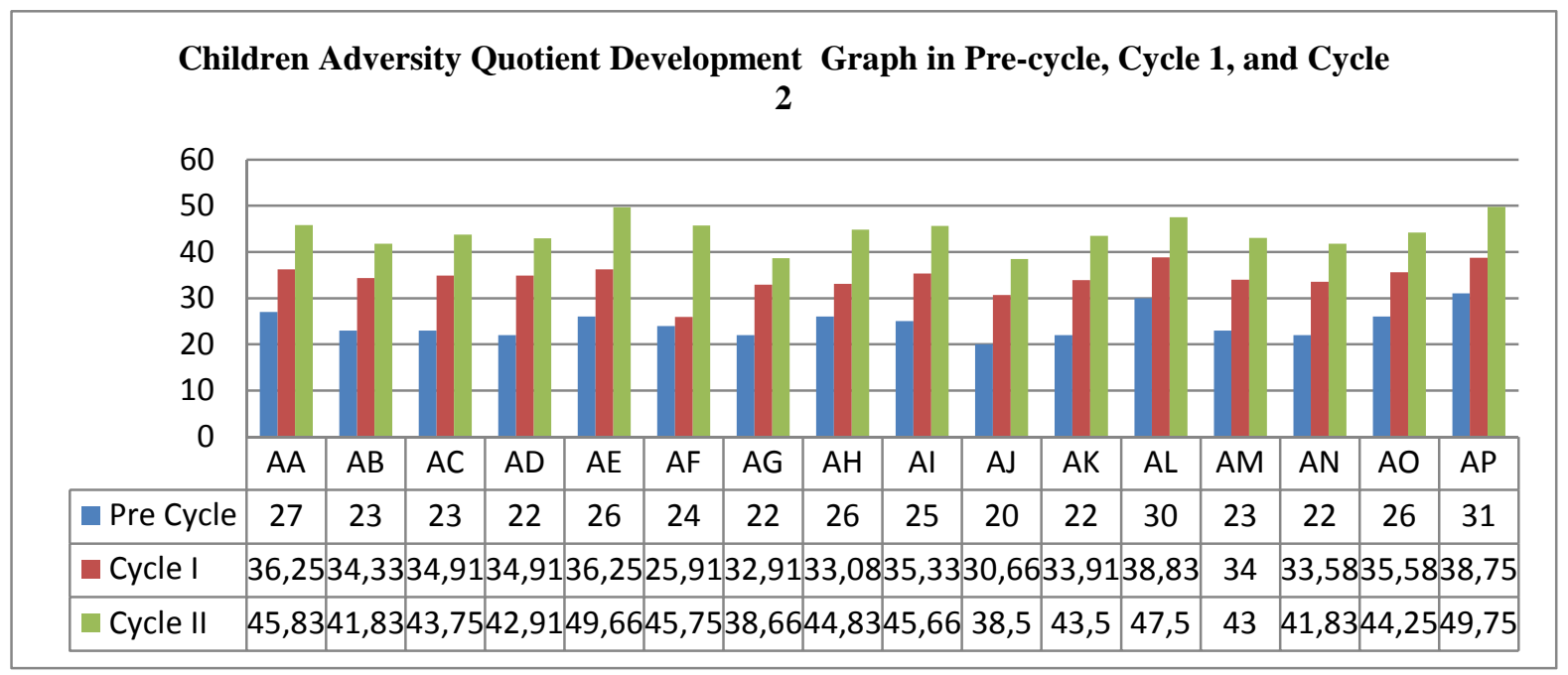

Figure 3. Cycle 2 Adversity Quotient Graphic to Group B Children of Kindergarten

Data in the table and the graph showing an increase in adversity quotient of Group B Pertiwi III Djetis Kindergarten with 16 people in total can be seen in the average pre-cycle DAL score that reached 24.31 points. DAL increase in the first cycle by 10.63 points to a total of 34.94 points and the second cycle of adversity quotient increase by 9.26 points to 44.20 points.

Based on the result of an agreement between the researcher and collaborator with regard to the criteria of success, that the study is said to be successful if $71 \%$ of the number of children or 12 children achieve minimum requirements that is previously specified with the collaborator which is 40.5 points of DAL score. Data on the second cycle showed that the average DAL of 44.20 points, with 14 of 16 children reached the minimum DAL of 40.5 points and above. It is proved that adversity quotient increased and reaches the target. So it can be said that playing outbound activities can improve children's adversity quotient.

\section{DISCUSSION}

Based on the results of the pre-cycle research, the first cycle, and the second cycle, adversity quotient begin to increase. The following data is an increase in the pre-intervention assessment results until the second cycle. Increase of adversity quotient group B Pertiwi III Djetis kindergarten totaling 16 people can be seen in the average DAL score in pre-intervention reaching 24.31 points. DAL increases in the first cycle by 10,63 points to 34,94 points and on second cycle adversity quotient of children increased by 9.26 points to 44.20 points total DAL score. As has been previously specified that if the value of the average grade reaches $71 \%$, the research is considered passed.

AP is the participant with the highest DAL score with pre-intervention DAL scores of 31 points, and after the first cycle it is increased by 7.75 points, to 38.75 points. From the first cycle to cycle II AP increases 7 score to adversity quotient (adversity quotient) with total of 14.75 points increase from the pre-cycle to the second cycle.

$\mathrm{AP}$ is a son of a truck driver and his mother is a farmer. AP is an independent child and because his parent has divorced AP is already accustomed to taking care of himself. Sometimes AP shows his sad face, but when he plays with his friend AP cheered back.

Respondent who has the lowest DAL is AJ. Based on data on pre-cycle, AJ's adversity quotient is at 20 points which increased by 10.66 points in first cycle 30.66 points. From the first cycle to the second cycle AJ increased by 8.16 points so the adversity quotient point total is 38.5 points. AJ 
increased adversity quotient from pre-intervention to the second cycle is 18.82 points. Based on AJ score in the second cycle, it can be said AJ increase has not reached the target, however it does not make teachers stop giving motivation to AJ. Teachers continue to provide advice, support and motivation to AJ to always have indomitable spirit, never give up and never give complaining. Cooperation with parents is also needed to increase his adversity quotient.

$\mathrm{AJ}$ is the son of a worker who works overseas and his mother is a housewife. AJ also an only child so that $\mathrm{AJ}$ get too spoiled resulting in AJ have less persistence in completing activities and $\mathrm{AJ}$ is also easy to complain.

Outbound activities provide obstacles to be solved or passed by the child with all the courage and fighting spirit. Improved adversity quotient through play activities is related to outbound multidisciplinary can be seen in the chart below:

By psychology playing outbound activity is fun and appropriate to the child's world. Vygotsky (2011: 58) says that learning involves the acquisition of the signs through teaching and information from others, the development involves of the child's appreciation of these signs so that they can think and solve.

From social science point of view as the science that covers all aspects of the life from a person or individual properties, interactions between individuals, between individuals and groups, and the interaction between the group and the group. Muhtar Latif (2013: 150) states that good communication helps children to develop his confidence, self-esteem and relationships with others. Outbound activities are activities that require good communication between the child and the child or children with the teacher

Judging from the study of Anthropology as the study of humans, Humans are required for lifelong learning. As Vygotsky in Margharet (2011: 377) of the biological heritage of both animals and humans is a process called signalization, this process is the introduction of stimuli that occur in an environment. As a young child put his hand on the hot stove and feeling the pain, as he approached the stove again he would remember the pain and act cautiously.

Likewise with outbound activities, children learn from the experience of each meeting. The child will get the experience and sailed to an event that illustrates cause and effect.

Judging from the science of early childhood education, early childhood development is an effort aimed at children from birth up to the age of six years that are accomplished by providing educational stimuli to help the growth and development of children physically and mentally in order to have the readiness to enter further education. Montesori (2013: 34) says that "for the child play is an enjoyable, voluntary, purposeful, and spontaneously chosen activity. Often it is creative as well, involving problem solving, learning, new social skills, new language and new physical skills "for children, game is an exciting voluntarily, knowingly, and spontaneous activity.

\section{CONCLUSIONS}

Based on the results of data analysis and discussion, it can be concluded as follows: adversity quotient can be enhanced through outbound activities, this can be seen from the increase in the average score of adversity quotient through outbound activities. Based on observations of the actions that have been done on 16 participants in the first cycle, it can be understood that adversity quotient of children had increased by 10.44 points from pre-cycle average scores of 24.31 points. And the first cycle to 34.94 points. In the second cycle of adversity quotient of children had increased by 9.26 points where children receive an average of 44.20 points. So at the end of the second cycle study is successful because of DAL exceeds the success criteria agreed by the researcher and collaborator.

The increase of adversity quotient of children is because outbound activities are fun and can make children challenged. Outbound activities present challenging games, So that the children are challenged to complete it until the finish line. Besides, it is conducted using interesting media. The way teachers demonstrate the games are innovative resulting in the children to be more attracted to pass through obstacles well. Outbound can hone children to have the tenacity, fighting spirit, endurance, unyielding, and creative thinking in solving problems or obstacles encountered. Outbound becomes effective because in general it is more memorable, packaged in games that provide obstacles in accordance with the stages of child development, and is conducted in open nature so that children have to face the nature and making it more memorable. Children record the activities that have been done deeper in memory and store it in the long run. Adversity Quotient of children who is developed including Productive emotion control, self-organization, describe on an event that shows a causal accurately, able to put the atmosphere (thoughts and feelings) in a variety of different contexts correctly, being responsible for difficulties experienced, and demonstrate creative problem solving skill. 


\section{REFERENCES}

A Michael Huberman and Matthew B Miles. (1989) .Quality Data Analysus; A sourcebook ofNew Method. USA:Ninth Printing.

Ahmad, Syarwani. (2013). Ketahanmalangan Kepemimpinan Kepala Sekolah. Yogyakarta: Pustaka Felicha.

Agustian, Ary ginanjar. (2011). Rahasia Sukses Membangun Kecerdasan Emosi dan spiritual ESQ Emotional Quotient Bedasarkan Enam Rukun Imam dan Lima Rukun Islam. Jakarta: Arga.

Ancok, Djamaludin. Outbound Management Training. Yogyakarta: UII Press. 2007.

Chanda, Ashok. (2007). Strategic Human Redource Technologies. New Delhi: Response Books.

Asti. Badiatul Muclis. (2011). Fun Outbound. Jogjakarta: Pustaka Pelajar.

Dzikron, Muhammad.( 2014). Model Permainan Outbound. Klaten: HIZBUL Wathan.

Gradler, Margaret E. (2011). Learning And Instruction. Jakarta: Kencana.

Haryanto Kandani.( 2010). The Achiever. Jakarta: PT.Elex Media Komputindo.

Latif, Mukhtar. (2013). Orientasi Baru Pendidikan Anak Usia Dini Teori dan Aplikasi. Jakarta: Kencana.

Liisa Valikangas, Ph. D. (2010). The Resilient Organization: How Adaptive Cultures Thrive Even When Strategy Fails. USA: McGraw-Hill Companies, Inc.

Mills Geoffrey E. (2000). Action Research: A Guide for the Teacher Researcher. New Jerset: Pearson Edukation.

Muhammad, As'adi. (2006). The Power of Outbound Training. Yogyakarta: Power Book.

Sanoesi, A Esnoe. (2010). Low Impact Games. Yogjakarta: Kanisius.

Santrock. John W. (2011). Life-Spam Development. Amerika: Erlangga.

Sanoesi, A Esnoe. (2010). Low Impact Games. Yogjakarta: Kanisius.

Slavin, Robert E. (2011). Psiklolgi Pendidikan. Jakarta. PT. Indeks,

Stoltz, Paul G. (2000). AQ Mengubah Hambatan Menjadi Peluang. Jakarta: PT. Grasindo.

Suyadi. (2013). Konsep Dasar Paud. Bandung: PT REMAJA ROSKARYA.

Trianto. (2011). Penelitian Tindakan Kelas. Jakarta: Prestasi Pustakaraya. 